\title{
Energetic and Ecologic Heat Pumps Evaluation in Poland
}

\author{
Sara Sewastianik ${ }^{1}$ and Andrzej Gajewski ${ }^{2, *(1)}$ \\ 1 Students' Scientific Society “Heat Engineer", Bialystok University of Technology, Wiejska Street 45 A, \\ 15-351 Białystok, Poland; sa.sewastianik@vp.pl \\ 2 Department of HVAC, Bialystok University of Technology, Wiejska Street 45 A, 15-351 Białystok, Poland \\ * Correspondence: a.gajewski@pb.edu.pl; Tel.: +48-797-995-923
}

Received: 19 August 2020; Accepted: 16 September 2020; Published: 22 September 2020

check for updates

\begin{abstract}
The purpose of the work is a comparison of indirect carbon dioxide emissions between the different heat pump types that operate in Polish climate conditions. The analysis embraces air-to-water heat pump, ground-to-water heat pump, water-to-water heat pump and water-to-water heat pump with separating heat exchanger in the selected towns one in each climatic zone in the country. The study starts from determining seasonal coefficient of performance in each location using heating degree days to estimate seasonal heat demand. Seasonal coefficient of performance values enable an assessment which kind of heat pump meets the European Union requirements in every location. Eventually, indirect $\mathrm{CO}_{2}$ emissions that is caused by electrical energy production, are estimated for every heat pump in each location. Ground-to-water heat pump and water-to-water heat pump satisfy these requirements in each climatic zone in Poland. Air-to-water heat pump would be an energetic and ecological viable on a condition that substantial changes were done in Polish electrical energy mix.
\end{abstract}

Keywords: heat pump; carbon dioxide emissions; ASHP; GSHP; WSHP

\section{Introduction}

On 8 October 2018, the Intergovernmental Panel on Climate Change (IPCC) published a report on the effects of global warming $1.5^{\circ} \mathrm{C}$ above pre-industrial levels. According to its content, if people as an international community do not engage in the activities aimed at slowing the rise of the average temperature on Earth, we will, among other things, lead to undesired profound transformation of the ecosystem, intensification of dangerous weather phenomena (the hurricanes, droughts, floods) and in the long run to destruction of the world we currently live in [1]. Therefore, the countries and international organizations carry out the actions aimed at curbing the phenomenon of global warming. One of the countermeasures taken by the European Union (EU) is the pursuit of energy production in a climatic neutral way [2]. One proposal is to replace the high-emission heat sources used in individual central heating systems by heat pumps. Heat pumps do not directly emit any pollutants into the atmosphere but indirect emissions arise during the production of energy necessary for their driving [3]. Due to their growing popularity, variety of heat sources or operating parameters, the European Commission has introduced regulations specifying the minimum value of the seasonal performance coefficient (SCOP) [4].

Lucia et al. [5] reviewed literature on heat pump from the technological and thermodynamic aspects. Heat pumps that use the ground as a heat source are divided into four categories. GWHPs, ground-water heat pump systems named also open-loop systems, are vertical open systems because water is drawn from a well and discharged to an appropriate outlet. GWHPs were firstly installed in 1940s. GCHP, ground-coupled heat pump systems named also closed-loop GSHP systems. These systems were 
developed in 1970s because of the problems with underground water quality and resources. The heat exchangers which are constructed with polyethylene pipes are buried in either the vertical boreholes or horizontal trenches. The heat exchangers are filled with water or antifreeze solution. The boreholes are refilled with a substance preventing ground water contamination. SWHP, surface water heat pump systems in which an open channel or basin filled with water is a heat source. This technology is yet developing. SCW, standing column well systems, in which water flows up and down in a standing column placed in a deep well bore. GSHP efficiency is determined in two ways. The first approach results from the first law of thermodynamics where efficiency is defined as a ratio of useful enthalpy and input enthalpy. The second law of thermodynamics takes into account a possibility for conversion of heat into a work. Hence, in the second law of thermodynamics the efficiency is defined as a ratio of output exergy and input exergy.

Kahraman and Çelebi [6] modelled a heat pump operation with a waste water tank as a heat source and hot water tank as a heat sink. Waste water temperature was $20^{\circ} \mathrm{C}, 30^{\circ} \mathrm{C}$ and $40^{\circ} \mathrm{C}$. Tap water was heated from $15{ }^{\circ} \mathrm{C}$ up to $49.4^{\circ} \mathrm{C}, 51.2^{\circ} \mathrm{C}$ and $55.6^{\circ} \mathrm{C}$ respectively. COP was in range 1.77-3.77 in dependence on mass flow rate through the hot water tank.

Nam et al. [7] carried out a dynamic simulation of solar-assisted ground heat pump system (SAGHPS). Regenerating lower temperature heat source resulted in increase of specific extraction rate at $28.8 \%$ and COP at $9.3 \%$.

Connoly et al. [8] considered a scenario for a 100\% renewable energy system in European Union before 2050 year. In the scope of heating Connoly et al. [8] recommend heat pumps for individual heating and district heating in urban areas.

Marinelli et al. [9] carried out life cycle assessment (LCA) of a heat pump prototype which is supplied with heat from either air or ground. The prototype operation was simulated in a humid subtropical climate conditions (Bologna in Italy). The assessment which ran "from the cradle to grave" showed the heat pump affects environment most during its usage. Another outcome was superiority of the dual-source heat pump to air source heat pump.

Jenkins et al. [10] estimated potential for carbon-saving heating in the UK. If temperature of supply water in a heating system is $35^{\circ} \mathrm{C}$ ground source heat pump (with COP $=4.4$ ) will emit $40 \%$ $\mathrm{CO}_{2}$ less than gas condensing boiler. Whereas the heating system working at $55^{\circ} \mathrm{C}$ saves $4 \% \mathrm{CO}_{2}$ (with COP $=2.8$ ).

Heat flux upwards and downwards a subsurface shallow depth soil layer was being measured for 10 year-period by Brys et al. [11] in the peripheral part of Wroclaw (Poland). Although, the ground can freeze up to $1 \mathrm{~m}$ in depth, the measured heat flux value are high enough the ground was an efficient heat source or sink for ground coupled heat pumps in the region.

Whereas in Prague (Czechia), Adamovsky et al. [12] measured positive temperature values in grounds at a depth $20 \mathrm{~cm}$.

Hence, there is a substantial difference between the temperature profiles in these neighboring countries.

Chwieduk [13] recommends ground, underground water basins or geothermal energy for large heating systems. While for the small heating systems the ground heat pumps are recommended.

Śliwa and Kotyza [14] recommend applying the wells from which water is not taken as a low temperature heat source for the heat pumps.

Nitkiewicz and Sekret [15] compared the electric heat pump, absorption heat pump and gas-fired boiler at a heat plant in Silesia (Poland) where geothermal water flows out in a natural way from unused boreholes. This water temperature is at $19.5^{\circ} \mathrm{C}$ and flow rate $24 \mathrm{~m}^{3} / \mathrm{h}$. The emissions from the gas boiler are the lowest and it does minor damage for both human health and ecosystem in comparison to the heat pumps.

Remiorz and Hanuszkiewicz-Drapała [16] analyzed the modernization of a heat generator of a power capacity of $10.2 \mathrm{~kW}$ in a residential building that is located in Silesia where the external design temperature is $-20^{\circ} \mathrm{C}$. After modernization will be two circuits the floor heating and domestic hot water. Heat generated by the heat pump will supply every circuit through a separate buffer tank. 
After a replacement an existing coal-fired furnace with a heat pump the emissions will be avoided as follows-1709 $\mathrm{t} \mathrm{CO}_{2}, 2.56 \mathrm{~kg} \mathrm{SO}_{2}, 1.62 \mathrm{~kg} \mathrm{CO}, 2.99 \mathrm{~kg} \mathrm{NO}$ and $0.32 \mathrm{~kg}$ dust.

A heat pump filled with zeotropic refrigerant R407C was tested by Szreder [17]. It produces heat for space heating and domestic hot water in a detached house. There are two underfloor heating loops the first one on the ground floor and the second one on the first floor. Every loop (ground floor heating, the first floor heating and domestic hot water circuit) is equipped with a pump. Three vertical U-tube ground heat exchangers, with separate glycol pomp for each, are used as a low temperature heat source. The more important outcomes are as follows. Circulation pump in the underfloor heating loops should work at the highest (2nd) gear, which causes larger mass flow rate and more turbulent flow, hence temperature in the condenser drops. As a result COP value increases. COP value greatly depends on glycol temperature in the underground loops. Applying inverter for driving a spiral compressor does not bring considerable economic benefits.

Pater [18] described the seven-year experiment, in a residential building located near Kraków (Poland), with a system equipped with gas condensing boiler, biomass boiler, solar collectors and ground source heat pump as the alternative heat generators. There were three circuits-central heating, domestic hot water and cooling. Annual seasonal performance factor for heat pump was between 3.5 and 3.8.

Szulgowska-Zgrzywa and Fidorów-Kaprawy [19] analyzed ground source heat pump operation in an office building located in Świdnica (Poland) in the third climatic zone. The heat pump unit was either a heat generator or cooling device. The central heating system was separated from the heat pump unit with a buffer tank. The solar collectors either were heating the buffer tank in the heating season or were regenerating ground around one of the boreholes when heating was turned off. Other borehole was regenerating when the heat pump was working as an air cooler. There were a total of 5 boreholes with a depth of $78 \mathrm{~m}$. Seasonal coefficient of performance (SCOP) was 4.05 without the buffer tank. Buffer tank which maintained constant temperature $40{ }^{\circ} \mathrm{C}$ decreases SCOP by $20 \%$.

Gajewski et al. [20] analyzed the operation of air, ground and groundwater heat pumps located in Bialystok (Poland). The climatic conditions were determined using ten-year mean temperature. In the case only groundwater heat pump emits less carbon dioxide than condensing gas boiler. Heat pumps supplied with heat from the air or ground would emit more carbon dioxide than condensing gas boiler.

\section{The Purpose of the Research}

A heat pump is not always more ecological than a condensing gas boiler, especially in countries where the majority of electricity production is done in the fossil-fuels plants. Heat pump usage should be promoted if their operation is energetically and ecologically profitable. Seasonal coefficient of performance (SCOP) is an averaged ratio which inform about energetic profitability. Coefficient of performance (COP) values that are the components of SCOP depend on temperature values in a heat source and heat sink and thermodynamic properties of a refrigerant. Carbon dioxide emissions may be applied as a factor of ecologic profitability. If total $\mathrm{CO}_{2}$ emissions caused by a heat pump are lower than by any fossil fuel boiler then heat pump may be considered as a "green" heat source.

Temperature values in the heat source depend on the climate conditions, its thermodynamic properties or geologic structure and heat exchange conditions. The most significant and rapid changes occur if external air is the heat source. Ground temperature changes gradually, while ground water temperature may be thought as constant.

Temperature conditions in the heat sink depend on flow temperature in a heating system that is a function of designed flow and return temperature in the heating system and external air temperature. External air temperature affects the flow temperature through a heating curve in a weather compensator.

Heat pumps performance is analyzed as either the device operation or the part of the system. The paper authors focus on the latter option. As bituminous coal and lignite combustion forms the overwhelming majority in the Polish energetic mix the aim of the pursued investigations is a comparison of carbon dioxide emissions in all the climatic zones in Poland. Hence, the shares of fossil fuels and the electricity production efficiencies as well as the efficiency of low voltage electricity 
transfer are the factors determined the Polish energetic mix. Moreover, an impact of the heating system on heat sink temperature is included in the analysis, which is made by taking a heating curve into account. Such an innovative approach is the goal of undertaken research. The emissions are estimated for air-to-water heat pump (ASHP), ground-to-water heat pump (GSHP) and water-to-water heat pump (WSHP). The purpose of the work is a comparison between indirect emissions for various types of heat pumps in Polish climate conditions.

\section{Methods and Assumptions}

An area of research is to determine the net values of the seasonal coefficient of performance $\left(S C O P_{n e t}\right)$ and carbon dioxide emissions of fixed-speed heat pumps that are the heat generators in a single-family house. 4 variants of available solutions on the market are analyzed-ASHP, GSHP, WSHP and water-to-water heat pump whose operation is preceded by a separation heat exchanger (WSHP+SHE). There are compared the heat pumps that are available on the market on the day of the test, they are enumerated in Table 1.

Table 1. Types of compared heat pumps manufactured by the Alpha Innotec company.

\begin{tabular}{cc}
\hline Heat Pump Type & Name of the Series \\
\hline air-to-water heat pump & LW140 \\
ground-to-water heat pump & SW172H3 \\
water-to-water heat pump & WWC 160HX \\
\hline
\end{tabular}

Heat pump is the only heat generator in a single-family house that total heated area is $280 \mathrm{~m}^{2}$. Insulation of walls, as well as window and door joinery complies with the requirements corresponding to the requirements for thermal insulation of partitions in buildings commissioned from 1 January 2017 specified in the applicable legal regulations [21-23]. The total designed heat load of the building is $14 \mathrm{~kW}$. The house is located in Bialystok. Due to the assumption that the presented analysis compares the operation of the same devices operating in the different climatic conditions, the same design heat load $14 \mathrm{~kW}$ in each selected location is assumed. Five selected locations, one of each of the Polish climatic zones (cf. Figure 1), were analyzed-Szczecin, Poznań, Łódź, Białystok, Zakopane (Table 2).

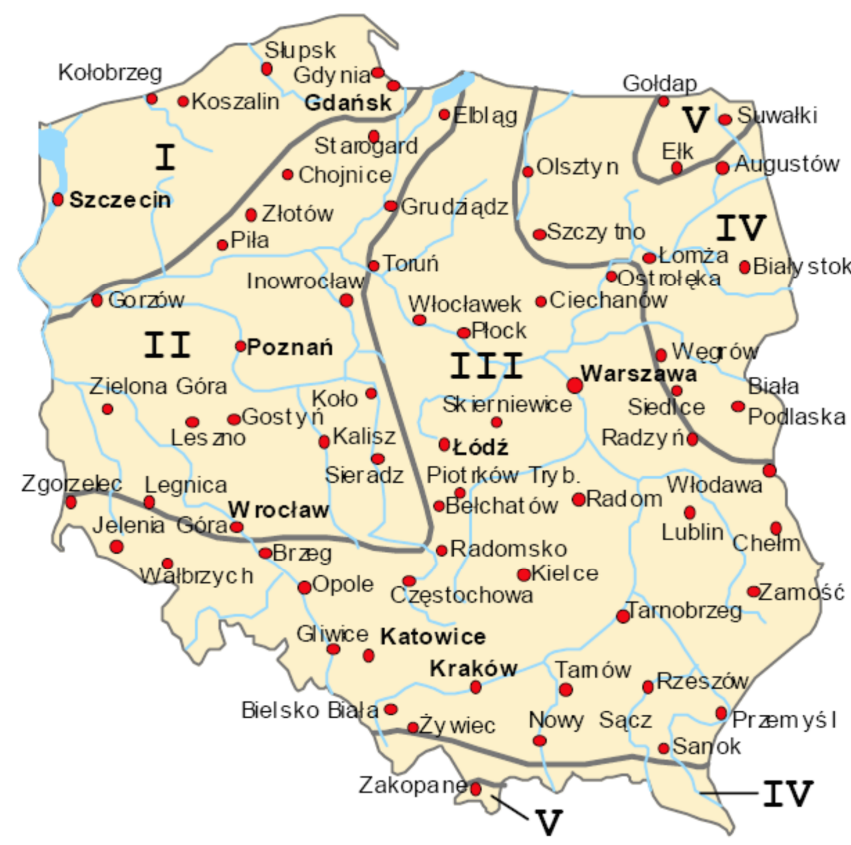

Figure 1. Poland divided into five climatic zones [24]. 
Table 2. Information on the climatic conditions in the analyzed localizations [24].

\begin{tabular}{|c|c|c|c|c|c|c|}
\hline \multirow{2}{*}{ Localization } & \multirow{2}{*}{ Month } & \multirow{2}{*}{$\begin{array}{c}\text { Number of } \\
\text { Heating Days (d) }\end{array}$} & \multirow{2}{*}{$\begin{array}{l}\text { Annual Temperature } \\
\text { Amplitude }\left({ }^{\circ} \mathrm{C}\right)\end{array}$} & \multirow{2}{*}{$\begin{array}{l}\text { Design Outside } \\
\text { Temperature }\left({ }^{\circ} \mathrm{C}\right)\end{array}$} & \multicolumn{2}{|c|}{ Average Temperature $\left({ }^{\circ} \mathrm{C}\right)$} \\
\hline & & & & & Variant I & Variant II \\
\hline 1 & 2 & 3 & 4 & 5 & 6 & 7 \\
\hline \multirow{9}{*}{$\begin{array}{c}\text { Szczecin } \\
\text { (I climatic zone) }\end{array}$} & January & 31 & \multirow{9}{*}{9.3} & \multirow{9}{*}{-16} & -1.2 & -5.9 \\
\hline & February & 28 & & & -0.7 & -5.4 \\
\hline & March & 31 & & & 2.5 & -2.2 \\
\hline & April & 30 & & & 7.2 & 2.6 \\
\hline & May & 10 & & & 12.4 & 7.8 \\
\hline & September & 20 & & & 13.5 & 8.9 \\
\hline & October & 31 & & & 8.9 & 4.3 \\
\hline & November & 30 & & & 4.4 & -0.3 \\
\hline & December & 31 & & & 1 & -3.7 \\
\hline \multirow{7}{*}{$\begin{array}{c}\text { Poznań } \\
\text { (II climatic zone) }\end{array}$} & January & 31 & \multirow[t]{7}{*}{10} & \multirow[t]{7}{*}{-18} & -2.2 & -7.2 \\
\hline & February & 28 & & & -1.4 & -6.4 \\
\hline & March & 31 & & & 2.1 & -2.9 \\
\hline & April & 30 & & & 7.4 & 2.4 \\
\hline & October & 31 & & & 8.6 & 3.6 \\
\hline & November & 30 & & & 3.7 & -1.3 \\
\hline & December & 31 & & & -0.1 & -5.1 \\
\hline \multirow{9}{*}{$\begin{array}{c}\text { Łódź } \\
\text { (III climatic zone) }\end{array}$} & January & 31 & \multirow[t]{9}{*}{10} & \multirow[t]{9}{*}{-20} & -3.2 & -8.2 \\
\hline & February & 28 & & & -2.3 & -7.3 \\
\hline & March & 31 & & & 1.5 & -3.5 \\
\hline & April & 30 & & & 7.2 & 2.2 \\
\hline & May & 5 & & & 12.5 & 7.5 \\
\hline & September & 5 & & & 13.1 & 8.1 \\
\hline & October & 31 & & & 8.2 & 3.2 \\
\hline & November & 30 & & & $\begin{array}{l}0.2 \\
3.3\end{array}$ & -1.7 \\
\hline & December & 31 & & & -0.8 & -5.8 \\
\hline \multirow{9}{*}{$\begin{array}{c}\text { Białystok } \\
\text { (IV climatic zone) }\end{array}$} & January & 31 & \multirow[t]{9}{*}{10.9} & \multirow[t]{9}{*}{-22} & -4.8 & -10.3 \\
\hline & February & 28 & & & -4.2 & -9.7 \\
\hline & March & 31 & & & -0.3 & -5.8 \\
\hline & April & 30 & & & 6.6 & 1.2 \\
\hline & May & 10 & & & 12.4 & 7 \\
\hline & September & 10 & & & 12.2 & 6.8 \\
\hline & October & 31 & & & 7.1 & 1.7 \\
\hline & November & 30 & & & 2.3 & -3.2 \\
\hline & December & 31 & & & -2 & -7.5 \\
\hline \multirow{9}{*}{$\begin{array}{c}\text { Zakopane } \\
\text { (V climatic zone) }\end{array}$} & January & 31 & \multirow[t]{9}{*}{9.3} & \multirow[t]{9}{*}{-24} & -5 & -9.7 \\
\hline & February & 28 & & & -3.8 & -8.5 \\
\hline & March & 31 & & & -0.6 & -5.3 \\
\hline & April & 30 & & & 4.5 & -0.2 \\
\hline & May & 20 & & & 9.4 & 4.8 \\
\hline & September & 20 & & & 10.2 & 5.6 \\
\hline & October & 31 & & & 5.9 & 1.3 \\
\hline & November & 30 & & & 1.3 & -3.4 \\
\hline & December & 31 & & & -2.8 & -7.5 \\
\hline
\end{tabular}

\subsection{Computation of Seasonal Coefficient of Performance}

The analysis is started from determining coefficient of performance value at each operating temperature $\left(\mathrm{COP}_{\text {bin }}\right)$. This value depends on both brine and outside temperature. Outside temperature is assumed to be equal to the mean value in a given month. This is due to the fact that heating degree days (HDD) represent different climatic conditions. Because COP is non-linear function of temperature and mean temperature value could overestimate the final test results, the second calculation option is considered. In this option COP depends on average minimal outside temperature that is the difference between the average monthly temperature and half of the monthly amplitude. The options discussed above are marked as "Variant I" and "Variant II" respectively.

Then the temperature values in every lower heat sources are determined. It should be emphasized that the higher reservoir temperature is, the lower electric energy for heat pump driving is demanded, which translates directly into $\mathrm{COP}_{\text {bin }}$ values. Eventually, the resultant SCOP affects the final ecological and economic viability. The temperature values of the lower source and their variability depend on the properties of a source and have an effect on a device applied in the installation.

When using ASHP, outside air is the lower temperature heat source. This means that its value is subjected to continuous fluctuations depending on the changes in the weather conditions. This results in a large diversity of $\mathrm{COP}_{\text {bin }}$ values. As temperature decreases, amount of heat from the source diminishes while necessary work rises. 
This problem is substantially reduced when a heating system is supplied from either of the other types of pumps. The changing external conditions have little effect on mean ground temperature because ground below the shallow zone has constant temperature. They have no impact on temperature in groundwater basin.

In the case of the GSHP, it is necessary to turn attention to the depth to which the heat source extends. It is equally important to determine the geological structure and geographical location. These pieces of information are necessary to correctly determine the temperature profile of the heat source. In the analysis, the temperature profile is determined using the Baggs formula modified by a team led by Olesiewicz-Popiel [25] for the northern hemisphere:

$$
t(z, \tau)=\left(t_{a}+\Delta t_{m}\right)-1.07 k_{v} A_{s} \exp \left(-0.00031552 z a^{-0.5}\right) \cos \left[\frac{2 \pi}{365}\left(\tau-\tau_{o}-0.018335 z a^{-0.5}\right)\right]\left({ }^{\circ} \mathrm{C}\right),
$$

where $\tau$ is a day number in the year, $z$ is the depth (m), $\Delta t_{m}$ is a difference between the ground temperature below the shallow zone and the average annual air temperature $\left({ }^{\circ} \mathrm{C}\right), k_{v}$ is a vegetation coefficient, $A_{s}$ is the amplitude of annual air temperature in every climatic zone respectively $\left({ }^{\circ} \mathrm{C}\right), a$ is the soil thermal diffusivity $\left(\mathrm{m}^{2} / \mathrm{s}\right), \tau_{o}$ is the phase of the air temperature wave (day), $t_{a}$ is an average annual air temperature in each climatic zone, respectively $\left({ }^{\circ} \mathrm{C}\right)$.

Equation (1) is averaged over time and depth to determining the mean annual ground temperature in each zone. $A_{s}$ and $t_{a}$ are taken from columns 4 and 6 in Table 2 respectively. Table 3 shows other data for the mean ground temperature computation.

Table 3. Data for mean ground temperature determination.

\begin{tabular}{|c|c|c|c|}
\hline $\begin{array}{c}\text { Difference between Ground Temperature below Shallow } \\
\text { Zone and Average Annual Air Temperature (a) }\end{array}$ & $\Delta t_{m}$ & $\left({ }^{\circ} \mathrm{C}\right)$ & 9.4 \\
\hline vegetation coefficient ${ }^{(a)}$ & $k_{v}$ & () & 0.85 \\
\hline the soil thermal diffusivity ${ }^{(a)}$ & $a$ & $\left(\mathrm{~m}^{2} / \mathrm{s}\right)$ & $5.50 \times 10^{-7}$ \\
\hline the phase of the air temperature wave ${ }^{(a)}$ & $\tau_{0}$ & (day) & 24 \\
\hline borehole depth & $L$ & $(\mathrm{~m})$ & 100 \\
\hline
\end{tabular}

(a) According to Reference [25]

In the case of an installation equipped with a WSHP, the groundwater basin is the lower heat source. When determining the value of the source temperature, the Kowalski [26] relation is used:

$$
t_{H}=t_{a}+A+g_{g}(H-h)\left({ }^{\circ} \mathrm{C}\right),
$$

where $t_{a}$ is average annual air temperature in each climatic zone respectively $\left({ }^{\circ} \mathrm{C}\right), A$ is a correction factor due to true altitude, $g_{g}$ is a geothermal gradient $\left({ }^{\circ} \mathrm{C} / \mathrm{m}\right), H$ is a depth of a groundwater basin level $(\mathrm{m}), h$ is the depth of the shallow zone $(\mathrm{m})$. The datum set and the results for further modelling are shown in Table 4.

Table 4. The groundwater basins data.

\begin{tabular}{ccccccc}
\hline & $\boldsymbol{t}_{\boldsymbol{a}}$ & $\boldsymbol{A}^{(\boldsymbol{a})}$ & $\boldsymbol{g}_{\boldsymbol{g}}{ }^{(\boldsymbol{b})}$ & $\boldsymbol{H}^{(\boldsymbol{c})}$ & $\boldsymbol{H}^{(\boldsymbol{a})}$ & $\boldsymbol{t}_{\boldsymbol{H}}{ }^{(\boldsymbol{b})}$ \\
\cline { 2 - 7 } & $\left.\mathbf{(}^{\circ} \mathbf{C}\right)$ & $\left({ }^{\circ} \mathbf{C}\right)$ & $\mathbf{(} \mathbf{C} / \mathbf{m})$ & $\mathbf{( m )}$ & $\mathbf{( m )}$ & $\left({ }^{\circ} \mathbf{C}\right)$ \\
\hline Szczecin & 8.3 & 0.81 & 0.023 & 22.5 & 15 & 9.3 \\
Poznań & 8.0 & 0.83 & 0.022 & 81.4 & 15 & 10.3 \\
Łódź & 7.6 & 0.86 & 0.024 & 66.5 & 15 & 9.7 \\
Białystok & 6.7 & 0.84 & 0.013 & 97.5 & 15 & 8.6 \\
Zakopane & 5.0 & 1.19 & 0.019 & 1010.7 & 15 & 24.9 \\
\hline${ }^{(a)}$ According to Reference [26]. ${ }^{(b)}$ According to Reference [27]. ${ }^{(c)}$ According to Reference [28].
\end{tabular}

When using a water-to-water pump, in addition to meeting the minimum and maximum source temperature requirements, it is necessary to compare the chemical composition compliance of the 
groundwater used with the requirements set by the device manufacturer. If these are not met, a separating heat exchanger (SHE) in the primary circuit should precede the heat pump in such a way the groundwater transfers heat to the brine, which causes the brine temperature decrease by 2 degrees. If temperature dropped below the minimal acceptable value by the manufacturer, then other after SHE GSHP would be installed. In the investigated cases, the WSHP + SHE units meet the manufacturer's requirements in each of the considered locations.

Knowing the values of the external temperature and lower heat sources, it is possible to move on to determining the most appropriate operating parameters of the installation. Due to the fact that the work of each device is controlled by the same weather compensator model, it is possible to select one heating curve, among those available in the control system used, along which each heat pump work is controlled. Heating curve, shown in Figure 2, in the algorithm is approximated by a square polynomial.

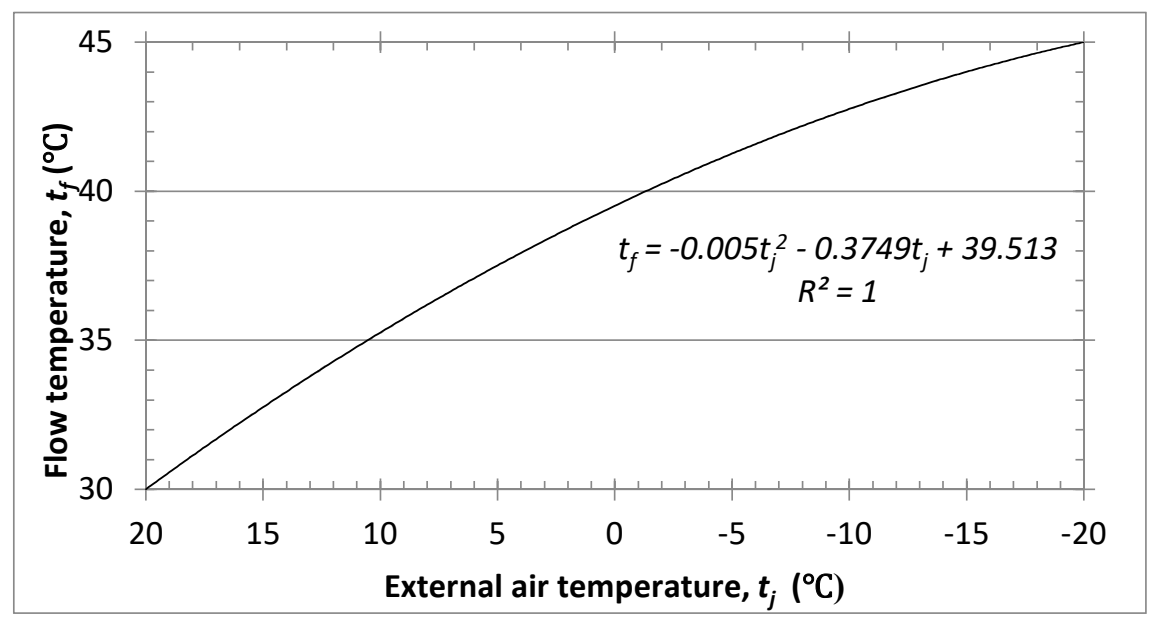

Figure 2. Heating curve selected in a weather compensator [29].

The next step is to determine the partial heat demand, which is done in accordance with the standard PN-EN 14825:2019-03 [30]:

$$
P_{h}\left(t_{j}\right)=\Phi_{i} \frac{\left(t_{i}-t_{j}\right)}{\left(t_{i}-t_{e}\right)}(\mathrm{kW}),
$$

where $\Phi_{i}$ is the total design heat load obtained using an algorithm from the standard PN-EN 12831-1:2017-08 [31], $t_{i}$ is the internal design temperature that equals $20{ }^{\circ} \mathrm{C}, t_{j}$ is the external air temperature, $t_{e}$ is the external design temperature.

The performance drop caused by the on-off cycles was not included in the calculations.

The seasonal coefficient of performance $\left(S C O P_{n e t}\right)$ value is determined based on the former standard [30]:

$$
\operatorname{SCOP}_{n e t}=\frac{\sum_{j=1}^{n} h_{j}\left[P_{h}\left(t_{j}\right)\right]}{\sum_{j=1}^{n} h_{j}\left[\frac{P_{h}\left(t_{j}\right)}{\operatorname{COP}_{\text {bin }}\left(t_{j}\right)}\right]}(-),
$$

where $h_{j}$ is the number of bin hours occurring at external temperature $t_{j}$ in the heating season, $\mathrm{COP}_{\text {bin }}\left(t_{j}\right)$ is COP value of the unit at external temperature $t_{j}, j$ is a number of a temperature value (the temperature values are sorted in ascending order).

\subsection{Determinating the Value of Pollutant Emissions}

In a central heating installation, pollutant emissions occur as a result of burning a fuel to generate heat in its needs (direct emission) and the fossil fuels combustion at the power plants to produce 
electricity for the heat source driving (indirect emission). Heat pumps cause no direct emission, because the heat is provided from zero-emission sources. The indirect emission value was determined on the basis of the Equation [32]:

$$
E=\beta_{a g} \sum_{j=1}^{n} h_{j}\left[\frac{P_{h}\left(t_{j}\right)}{C O P_{b i n}\left(t_{j}\right)}\right](\mathrm{kg}),
$$

where $\beta_{a g}$ is an aggregate pollutant generation factor which accounts direct and indirect emissions amid electrical energy production and considers shares of all the fuels in Polish energy market (cf. PGE 2020).

Information on the share of individual sources used for the production of electricity used by the heat pump is consistent with the data on the fuel structure provided by PGE [33] and is presented in Table 5. Ciura [34] estimated the low voltage electricity transfer efficiency at $79.2 \%$

Table 5. The shares of the energy sources in electricity production in Poland [33].

\begin{tabular}{cccc}
\hline Energy Source & Generation Factor & $\begin{array}{c}\text { Share of a Fuel in } \\
\text { Electricity Production }\end{array}$ & $\begin{array}{c}\text { Electricity } \\
\text { Production Efficiency }\end{array}$ \\
\hline Bituminous coal & $\left(\mathrm{kgCO}_{2} / \mathrm{GJ}\right)$ & & \\
Lignite & 224.78 & $43.08 \%$ & $36.00 \%$ \\
Natural gas & 295.84 & $46.23 \%$ & $36.00 \%$ \\
Renewables & 87.34 & $6.68 \%$ & $34.00 \%$ \\
Others & 0.00 & $3.78 \%$ & - \\
\hline
\end{tabular}

Based on the Equation (5) it can be clearly seen that the environmental impact of a heat pump operation depends not only on the one's energy conversion ratio but also on the energy market in a given country. The high percentage of electricity generation from renewable, zero-emission energy resources in the overall balance results in lower indirect emissions.

\section{Results and Discussion}

The graph of $\mathrm{COP}_{\text {bin }}$ values for the 4 analyzed heat pumps is presented in Figure 3 which shows that regardless of the type of device used and its location, the $\mathrm{COP}_{\text {bin }}$ value increases as the outside air temperature rises. This is due to the fact that with the higher temperature difference between hotter and colder sources the work needed to driving a device grows. $\mathrm{COP}_{\text {bin }}$ value for ASHP is effected directly with the outside temperature changes. An impact of these changes on ground temperature is significantly reduced but not completely lost, which stems from Equation (1). Groundwater temperature is independent of outdoor temperature changes. COP values drop steady for GSHP, WHSP and WSHP + SHE as outside temperature goes down. In the case of ASHP, there are observed sharp bends as temperature falls to about $7^{\circ} \mathrm{C}$ and then marked reduction in the plots for zones I to $\mathrm{V}$ respectively. In the case of the ASHP pump, in each location, a sudden decrease in the COP value is noticeable when the outside air temperature drops below $7^{\circ} \mathrm{C}$. It is related to the evaporation pressure decrease which increases the pressure difference between the front and rear of the compressor. Thus compressor electrical energy consumption rises. Simultaneously, outside temperature drop raises heat demand. Consequently, $\mathrm{COP}_{\text {bin }}$ values rapidly decreases, which is illustrated in the instruction manual [29]. 


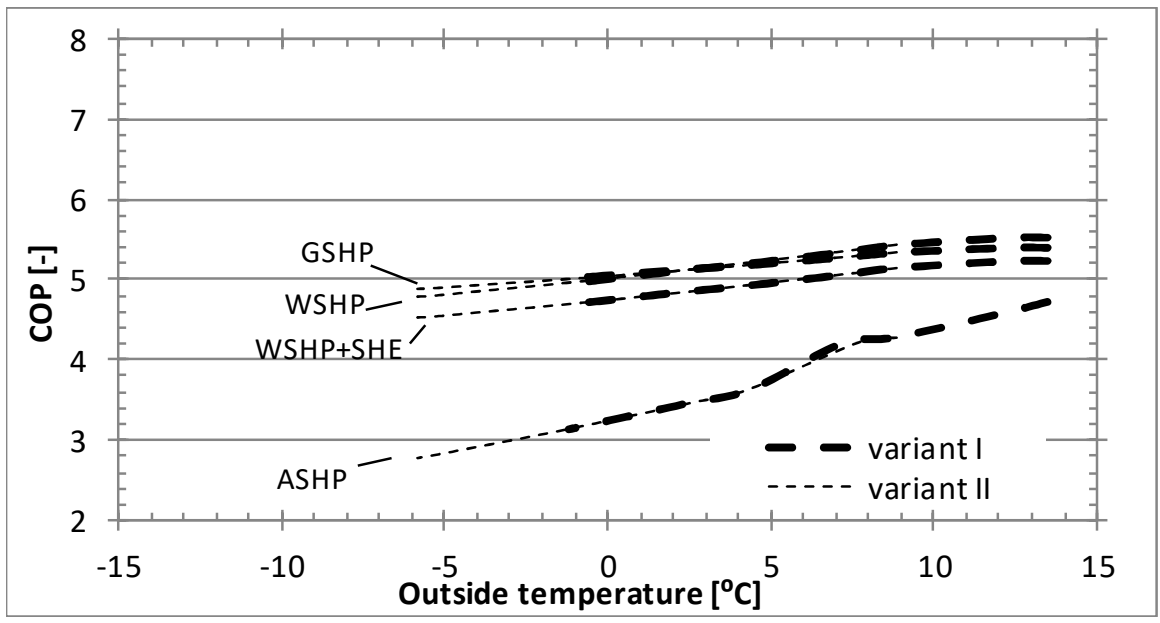

(a) Szczecin

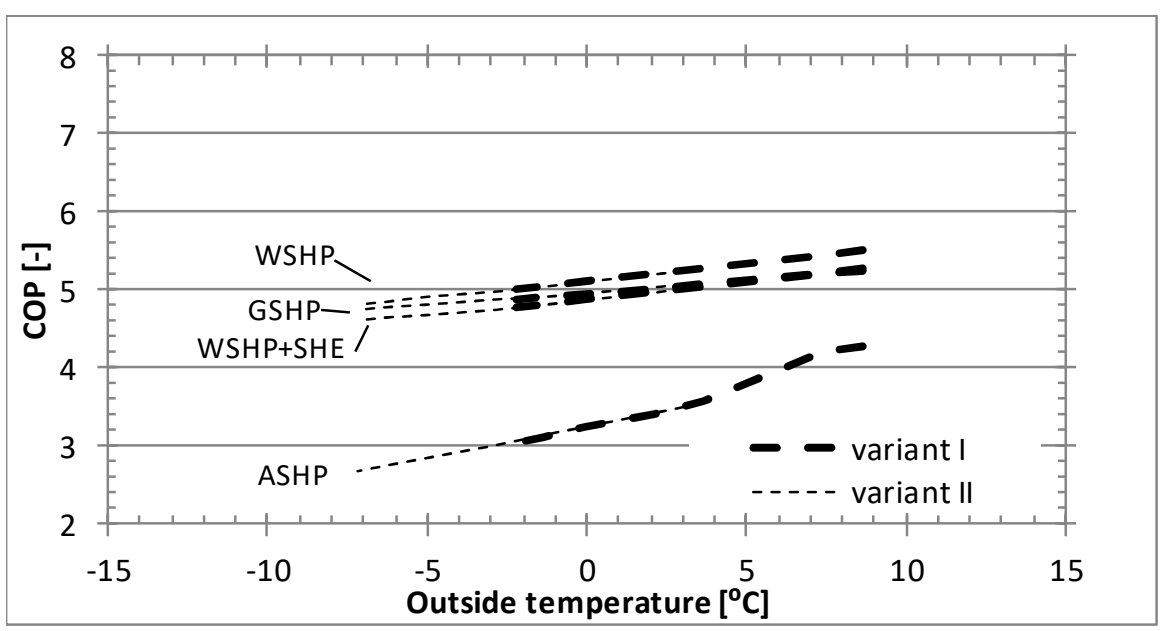

(b) Poznań

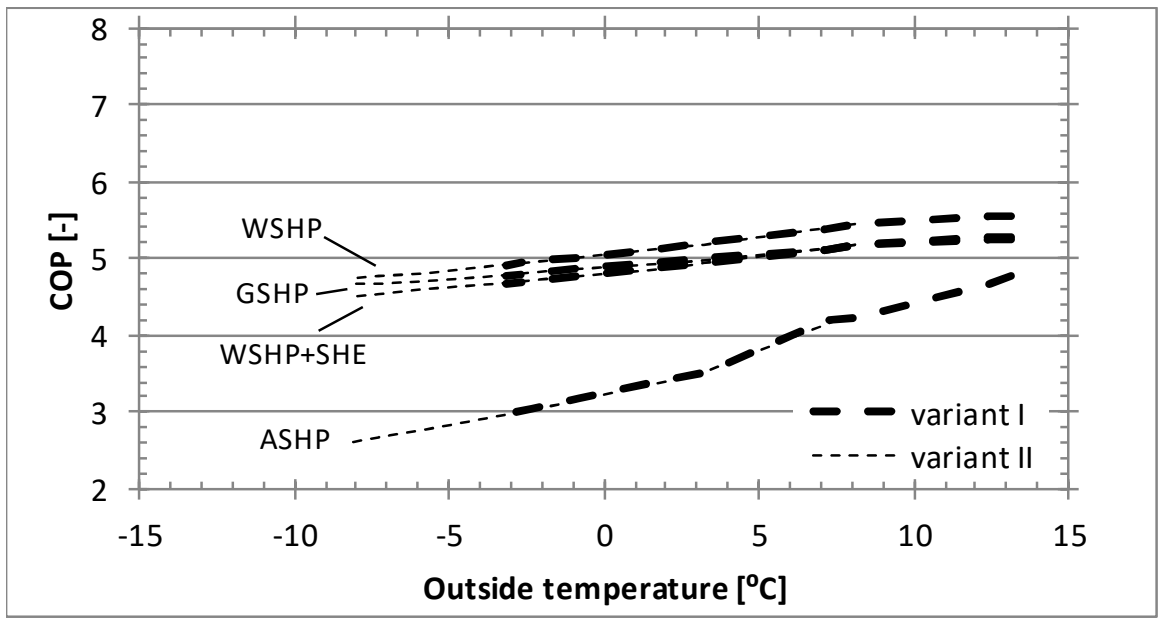

(c) Łódź

Figure 3. Cont. 


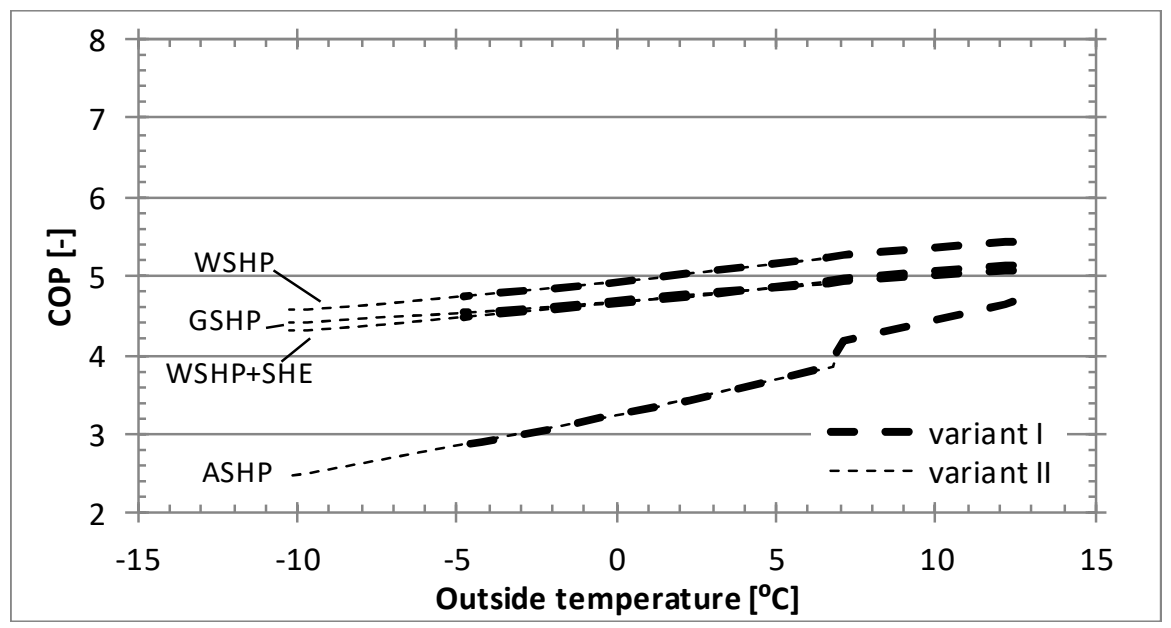

(d) Białystok

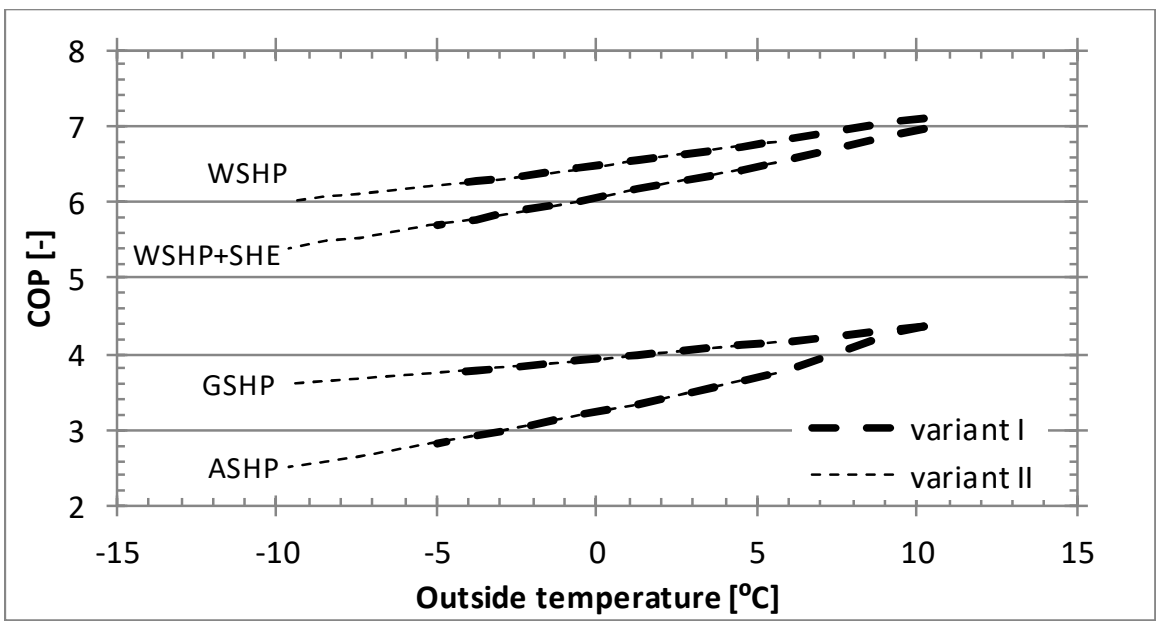

(e) Zakopane

Figure 3. $\mathrm{COP}_{\text {bin }}$ values depending on the outdoor temperature in each investigated location: (a) zone I (Szczecin), (b) zone II (Poznań), (c) zone III (Łódź), (d) zone IV (Białystok), (e) zone V (Zakopane).

Only in the case of I climatic zone the GSHP is characterized by higher $\mathrm{COP}_{\text {bin }}$ values than WSHP. It is observed at the lowest assumed operating temperature (in variant II) when $\mathrm{COP}_{\text {bin }}$ values are 4.88 for the former and 4.79 for the latter. For the highest temperature value (in variant I), the reciprocal relation is opposite. Here the $\mathrm{COP}_{\text {bin }}$ values are 5.41 and 5.53, respectively. Such a situation stems from the shallowest depth of the groundwater basin in Szczecin (cf. Table 4) and the highest temperature value (cf. Table 2), which results in the smallest temperature difference between groundwater and ground. In other locations this difference is greater, thus WSHP is more effective in comparison to GSHP in the full outside temperature range. It should be emphasized this superiority decreases with temperature drop. In the case of zone II, $\mathrm{COP}_{\text {bin }}$ values at the lowest temperature in the second variant are for WSHP and for GSHP 4.83 and 4.75, respectively. Similarly, in zone III COP bin $_{\text {equals }} 4.74$ and 4.66 and in zone IV the values are 4.56 and 4.4, respectively. The comparison of $\mathrm{COP}_{\text {bin }}$ values between GSHP and WSHP+SHE is equally interesting. In the case of zones II-IV, these values almost coincide at the upper temperature limit. In the case of zones II and III the value difference is 0.03 (zone II-for GSHP 5.25, for WSHP 5.28, zone III-for GSHP 5.26, for WSHP 5.29), while in zone IV it is 0.05 (for GSHP 5.08, for WSHP 5.13). The relative shift between the graphs of GSHP and WSHP (zone I) or GSHP and WSHP + SHE (zones II-IV) results from the temperature difference between the ground and groundwater. In the first climatic zone, the ground temperature is lower than the groundwater temperature and simultaneously higher than the brine temperature after SHE, which causes the GSHP and WSHP curves intersect. In other cases, 
the temperature of the ground is lower than both the groundwater temperature and brine temperature after SHE. This leads to the intersection of the GSHP and WSHP + SHE curves at the same temperatures as in zone I. Unlike is in the fifth climatic zone because of the great groundwater basin depth which results in considerable temperature difference between groundwater and ground. In the first variant $\mathrm{COP}_{\text {bin }}$ values for GSHP (4.36), ASHP (4.35) are almost equal at the highest temperature. Slightly more difference is between WSHP (7.09) and WSHP + SHE (6.95).

$S C O P_{n e t}$ values in every climatic zone are summarized in Figure 4.

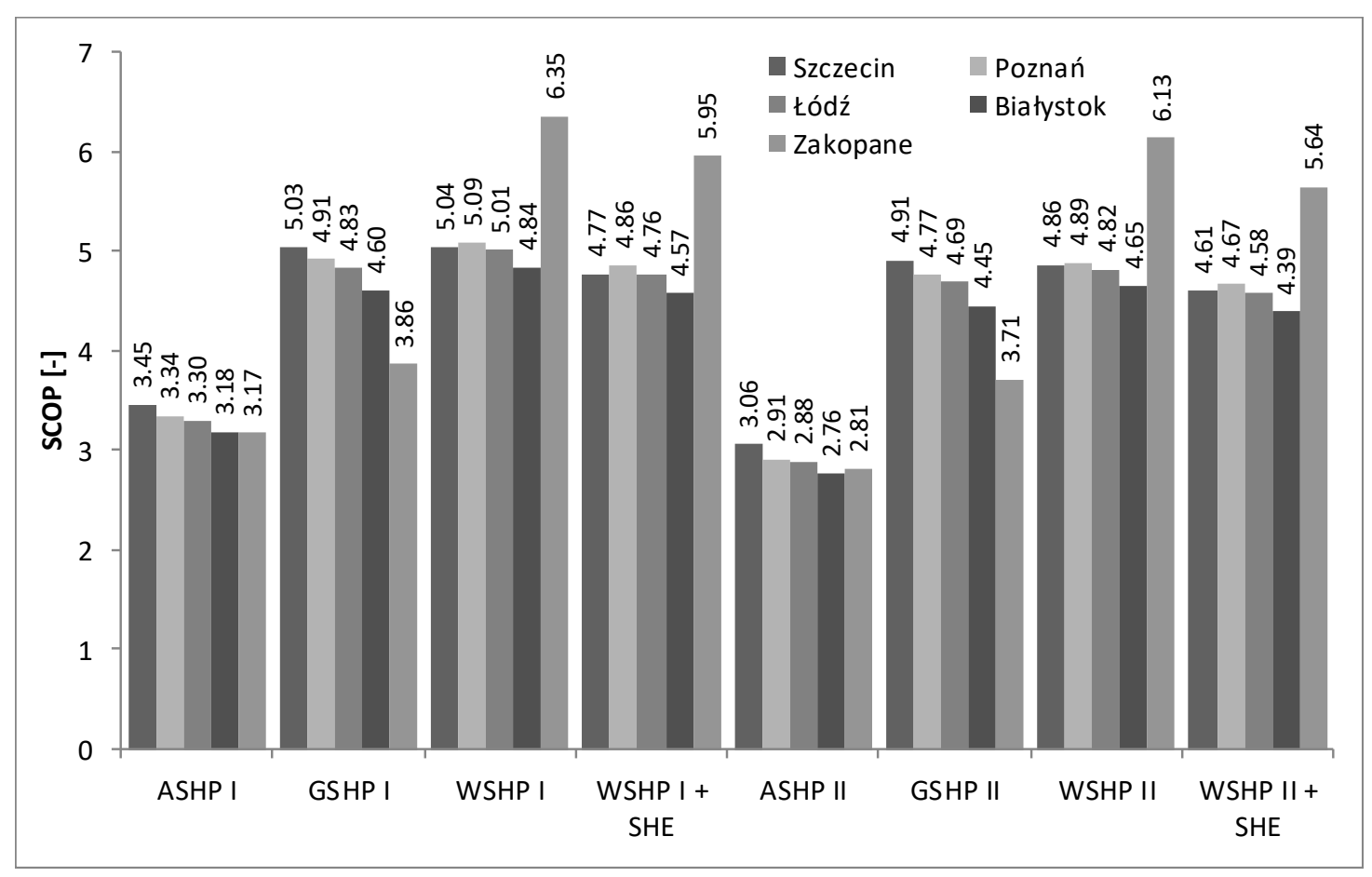

Figure 4. $S C O P_{\text {net }}$ values in each climatic zone in Poland in the variants I and II.

According to the recommendations issued by the European Commission on 1 March 2013, only those heat pumps that are energetically viable may be applied [35]. To satisfy this rule, in the conditions of the Polish energy mix, the SCOP net value should be at least 3.5 [32]. Figure 4 shows ASHP does not meet this condition in any of the analyzed zones. Hence, devices of this type cannot be considered in Poland as alternative, environmentally friendly heat generators. Otherwise is in the cases of GSHP and WSHP which meet this condition in each climatic zone. However, there are visible differences in comparison to individual locations resulting from the difference in hydrological or geological conditions between individual regions.

$S C O P_{n e t}$ values are higher for the I variant than in the II variant, which results directly from the higher values of the assumed external temperatures. The high $S C O P_{n e t}$ values of GSHP or WSHP are also influenced by warmer temperature as well as greater temperature stability of the respective colder sources. In Szczecin SCOP net values for GSHP and WSHP differ about 1\%, while GSHP outstrips WSHP + SHE by 5\% in both variants. In Poznań, Łódź and Białystok SCOP net values for WSHP are higher than GSHP by $4-5 \%$ in the first variant and by $2-4 \%$ in the second one. Contrastively, GSHP is more effective than WSHP + SHE by 1-2\% in both variants. In Zakopane WSHP and WSHP + SHE predominate GSHP by $52-65 \%$ in both variants.

Since, COP is inversely proportional to electrical energy demand and all the emissions are directly proportional to electricity usage, the results are in inverse proportion. In Szczecin electricity consumption and emissions for GSHP and WSHP are almost equal, while these values are greater by 6\% for WSHP + SHE. In Poznań, Łódź and Białystok energy demand and emissions WSHP are less 
than GSHP by $3-5 \%$ in the first variant and by $2-4 \%$ in the second one. In contrast GSHP uses less energy and emits less pollutions by $1-2 \%$ than WSHP + SHE in both variants. In Zakopane WSHP and WSHP + SHE save 35-40\% energy and equally reduce emissions with relation to GSHP.

Since, $\mathrm{COP}$ values are determined using the algorithm which assumes constant monthly outdoor air temperature and COP is not a linear function of temperature, the $S C O P_{\text {net }}$ values might be overestimated. Especially, when outside temperature drops up to $-30^{\circ} \mathrm{C}$, while the lowest mean value is 2.76 in zone IV and 2.81 in zone $\mathrm{V}$.

The differences between the results obtained in the options I and II are also visible in the case of electricity demand shown in Figure 5. Variant II shows clearly higher energy consumption. It is caused by lower assumed values of external temperatures and thus the necessity of incurring higher energy outlays in order to ensure an adequate amount of heat.

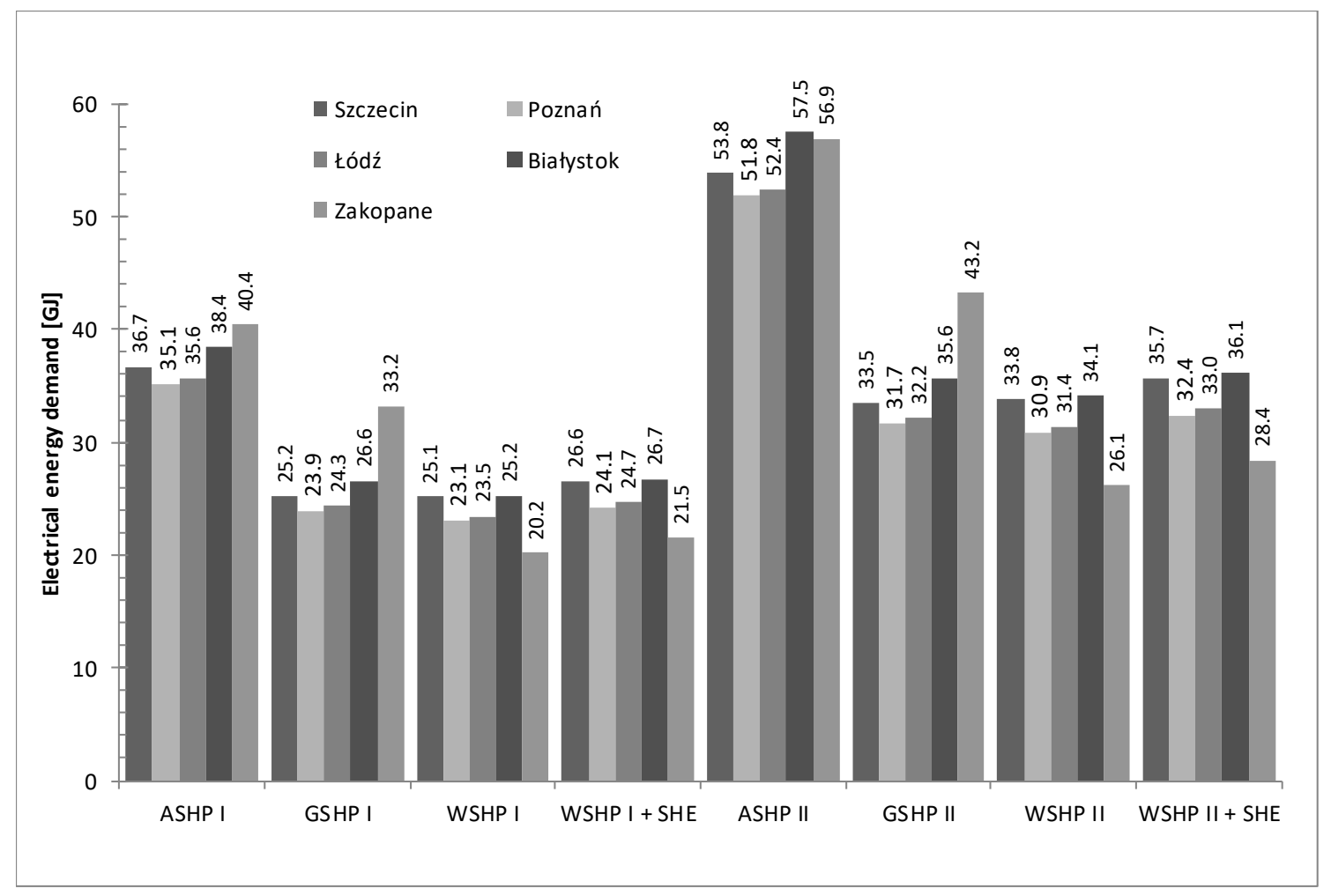

Figure 5. A summary of the energy demand for each heat pump in the variants I and II.

This translates directly into emissions presented in Figures 6-9. In the case of ASHP, where the demand for electricity is the highest, we observe the highest pollutions emissions in each zone. Heat pump that is supplied from a constant temperature heat source causes less indirect pollutions emissions. Regardless of a location and technological variant of an applied device, the by-product that is emitted in the largest amount is carbon dioxide. This is directly related to the fact that the current energy policy is based primarily on natural fossil raw materials, which are mainly composed of compounds containing carbon atoms. In the case of the remaining pollutants analyzed in this study, that is, sulfur dioxide and nitrogen dioxide as well as particulate matter (PM), the level of indirect seasonal emissions is similar.

It should be emphasized that it is always necessary to perform an analysis of running and investment costs. The analysis should also include thorough tests determining either physicochemical or geological parameters of the proposed colder heat source, since this affects the final value of SCOP and thus the overall costs of the installation. 


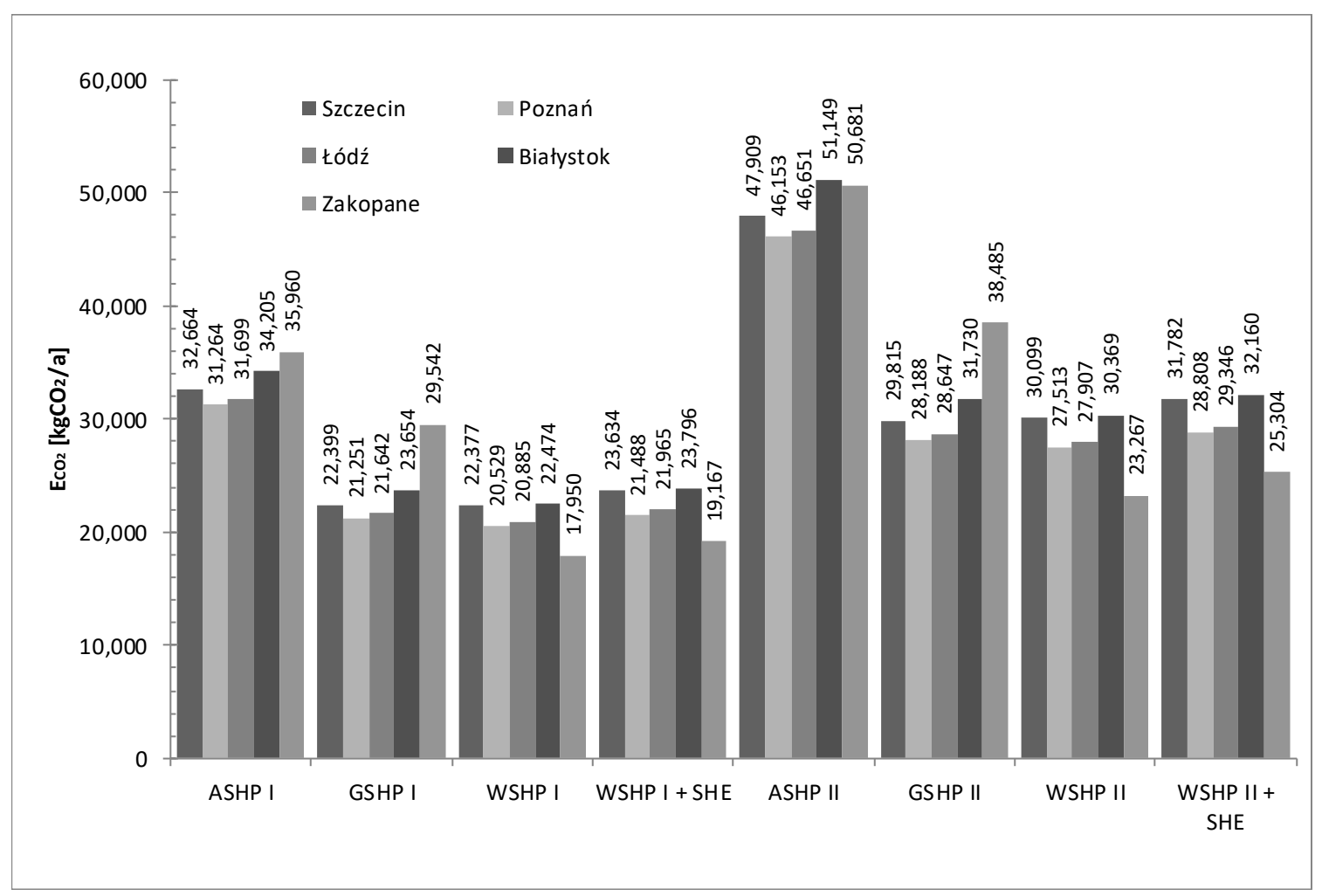

Figure 6. Indirect emissions of carbon dioxide values for specific locations in the variants I and II.

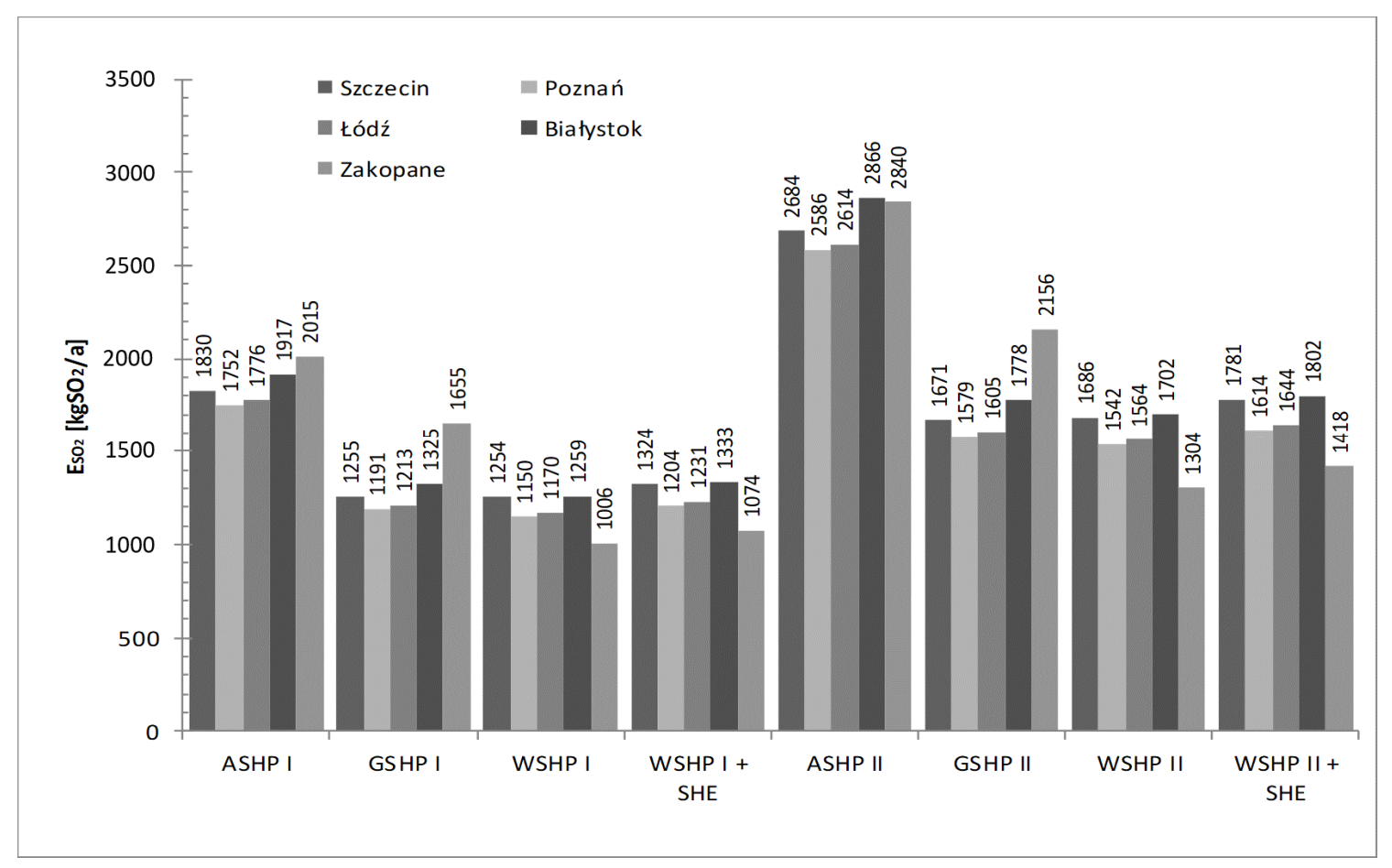

Figure 7. Indirect emissions of sulphur dioxide values for specific locations in the variants I and II. 


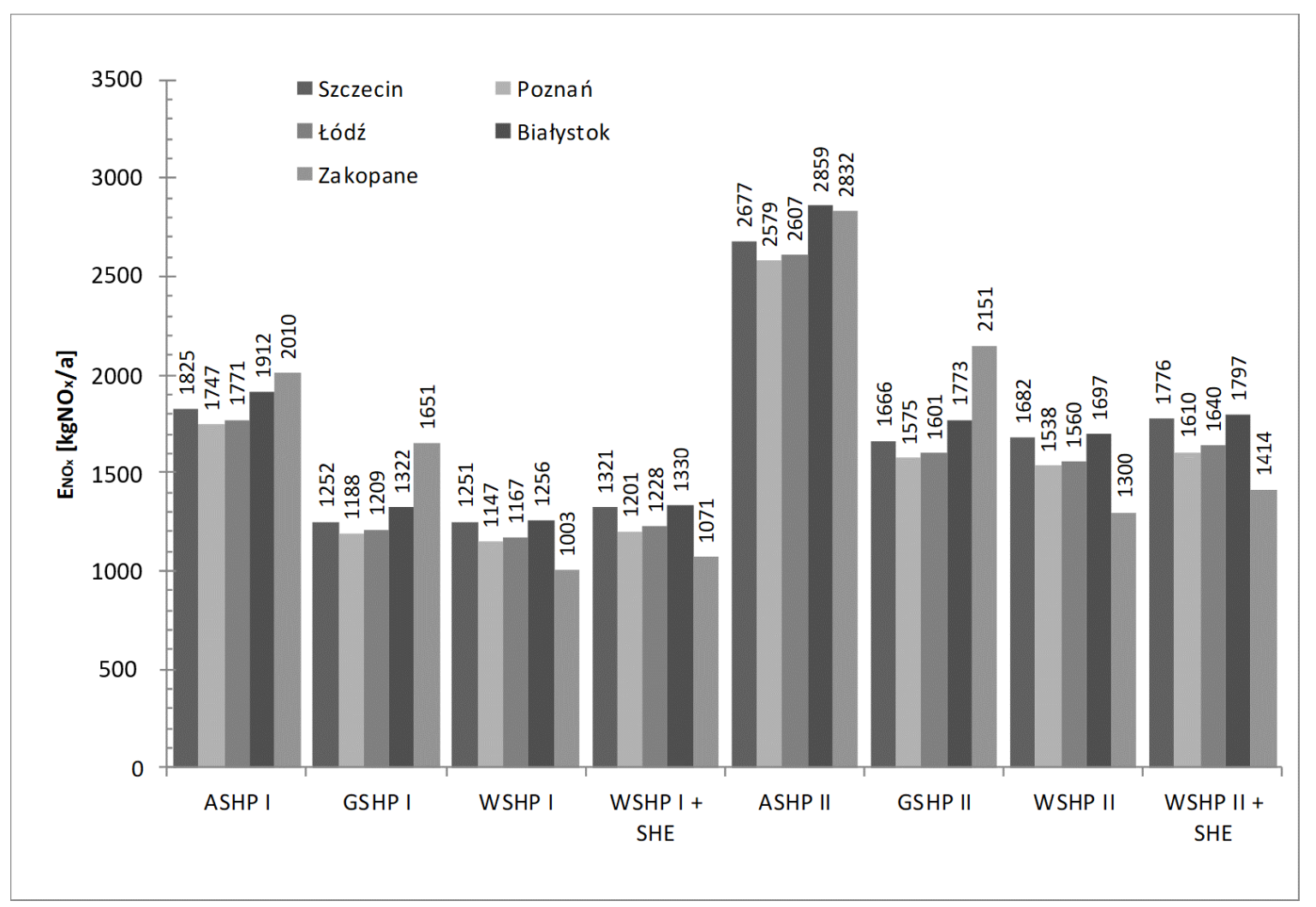

Figure 8. Indirect emissions of nitrogen oxides values for specific locations in the variants I and II.

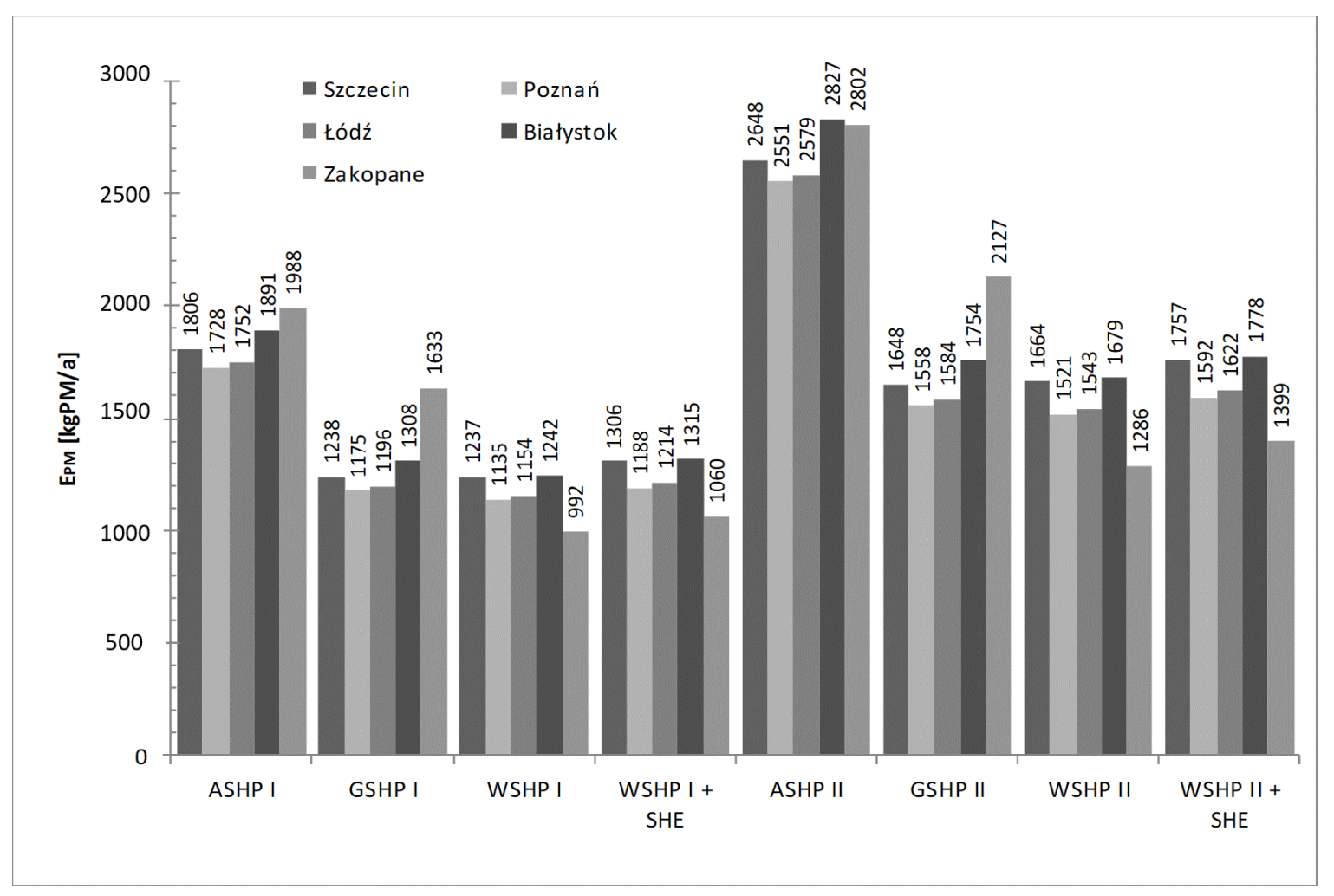

Figure 9. Indirect emissions of PM values for specific locations in the variants I and II. 


\section{Conclusions}

Considering the value of the seasonal energy efficiency ratio and emission levels, is is justified to state that in the Polish climate and with the energy mix conditions, both ground-to-water and water-to-water heat pumps are energetically viable and meet the conditions of an ecological heat source in accordance with the applicable European Union regulations; the wider application of these heat pumps could reduce the emissions caused by space heating. In the case of air-to-water heat pumps, it is necessary to introduce deep changes in the energy market in advance so that this device could be considered an ecological alternative. Moreover, the air-to-water heat pump is an energetically nonprofitable heat generator in the Polish energy mix. The final decision on choosing the type of heat pump should be preceded by an in-depth analysis of local temperature, geological, hydrological conditions and economic costs.

Author Contributions: S.S. and A.G. developed a calculation algorithm, S.S. computed SCOP, A.G. computed emissions, S.S. and A.G. analyzed the data and wrote the paper. All authors have read and agreed to the published version of the manuscript.

Funding: The paper was prepared at Students' Scientific Society "Heat Engineer" at Bialystok University of Technology and were financed by this university. The research was carried out at the Bialystok University of Technology at the Department of HVAC Engineering as the project WZ/WBiIŚ/4/2019 and was subsidised by the Ministry of Science and Higher Education of the Republic of Poland from funding for statutory R\&D activities. The research was conducted using equipment which was purchased thanks to either "INNO-EKO-TECH" Innovative research and didactic center for alternative energy sources, energy efficient construction and environmental protection-project implemented by the Technical University of Bialystok (PB), co-funded by the European Union through the European Regional Development Fund under the Programme Infrastructure and Environment or "Research on the efficacy of active and passive methods of improving the energy efficiency of the infrastructure with the use of renewable energy sources"-project was co-financed by the European Regional Development Fund under the Regional Operational Programme of the Podlaskie Voivodship for the years 2007-2013.

Conflicts of Interest: The founding sponsors had no role in the design of the study; in the collection, analyses or interpretation of data; in the writing of the manuscript and in the decision to publish the results.

\section{References}

1. Masson-Delmotte, P.V.; Zhai, H.-O.P.; Pörtner, D.; Roberts, J.; Skea, A.; Pirani, P.; Shukla, W.R.; Moufouma-Okia, C.; Péan, R.; Pidcock, S. Global Warming of $1.5^{\circ} \mathrm{C}$. An IPCC Special Report on the Impacts of Global Warming of $1.5^{\circ} \mathrm{C}$ Above Pre-Industrial Levels and Related Global Greenhouse Gas Emission Pathways; Intergovernmental Panel on Climate Change: Geneva, Switzerland, 2019.

2. European Commission. Communication from the Commission to the European Parliament, The European Council, The Council, The European Economic and Social Committee, The Committee of the Regions and The European Investment Bank; Publications Office of the European Union: Brussels, Belgium, 2018.

3. Carvalho, A.; Mendrinos, D.; De Almeida, A. Ground source heat pump carbon emissions and primary energy reduction potential for heating in buildings in Europe-Results of a case study in Portugal. Renew. Sustain. Energy Rev. 2015, 45, 755-768. [CrossRef]

4. European Union. Directive 2009/28/EC of The European Parliament and of The Council of 23 April 2009. Official Journal of the European Union. 23 April 2009. Available online: https://eur-lex.europa.eu/LexUriServ/ LexUriServ.do?uri=OJ:L:2009:140:0016:0062:en:PDF (accessed on 4 July 2019).

5. Lucia, U.; Simonetti, M.; Chiesa, G.; Grisolia, G. Ground-source pump system for heating and cooling: Review and thermodynamic approach. Renew. Sustain. Energy Rev. 2017, 70, 867-874. [CrossRef]

6. Kahraman, A.; Çelebi, A. Investigation of the performance of a heat pump using waste water as a heat source. Energies 2009, 2, 697-713. [CrossRef]

7. Nam, Y.; Gao, X.Y.; Yoon, S.H.; Lee, K.H. Study on the performance of a ground source heat pump system assisted by solar thermal storage. Energies 2015, 8, 13378-13394. [CrossRef]

8. Connolly, D.; Lund, H.; Mathiesen, B.V. Smart energy Europe: The technical and economic impact of one potential 100\% renewable energy scenario for the European Union. Renew. Sustain. Energy Rev. 2016, 60, 1634-1653. [CrossRef] 
9. Marinelli, F.S.; Lolli, M.A.B.; Gamberini, R. Environmental performance analysis of a dual-source heat pump system. Energy Build. 2020, 223, 110180-110192. [CrossRef]

10. Jenkins, D.; Tucker, R.; Rawlings, R. Modelling the carbon-saving performance of domestic ground-source heat pumps. Energy Build. 2009, 41, 587-595. [CrossRef]

11. Bryś, K.; Bryś, T.; Sayegh, M.A.; Ojrzyńska, H. Characteristics of heat fluxes in subsurface shallow depth soil layer as a renewable thermal source for ground coupled heat pumps. Renew. Energy 2020, 146, 1846-1866. [CrossRef]

12. Adamovsky, P.; Neuberger, D.; Adamovsky, R. Changes in energy and temperature in the ground mass withhorizontal heat exchangers-The energy source for heat pumps. Energy Build. 2015, 92, 107-115. [CrossRef]

13. Chwieduk, D.A. Analysis of utilisation of renewable energies as heat sources for heat pumps in building sector in Poland. Renew. Energy 1996, 9, 720-723. [CrossRef]

14. Sliwa, T.; Kotyza, J. Application of existing wells as ground heat source for heat pumps in Poland. Appl. Energy 2003, 74, 3-8. [CrossRef]

15. Nitkiewicz, A.; Sekret, R. Comparison of LCA results of low temperature heat plant using electric heat pump, absorption heat pump and gas-fired boiler. Energy Convers. Manag. 2014, 87, 647-652. [CrossRef]

16. Remiorz, L.; Hanuszkiewicz-Drapała, M. Cumulated energy consumption in a heat pump system using a U-tube ground heat exchanger in a moderate climate. Energy Build. 2015, 96, 118-127. [CrossRef]

17. Szreder, M. A field study of the performance of a heat pump installed in a low energy house. Appl. Therm. Eng. 2014, 71, 596-606. [CrossRef]

18. Pater, S. Field measurements and energy performance analysis of renewable energy source devices in a heating and cooling system in a residential building in southern Poland. Energy Build. 2019, 199, 115-125. [CrossRef]

19. Szulgowska-Zgrzywa, M.; Fidorów-Kaprawy, N. Performance analysis of a brine-to-water heat pump and of its boreholes' temperature change during three years of operation. Appl. Therm. Eng. 2017, 127, $233-244$. [CrossRef]

20. Gajewski, A.; Gładyszewska-Fiedoruk, K.; Krawczyk, D.A. Carbon dioxide emissions during air, ground, or groundwater heat pump performance in Białystok. Sustainability 2019, 11, 5087. [CrossRef]

21. The European Parliament and the Council of the European Union. Directive 2010/31/Eu of The European Parliament and of The Council of 19 May 2010 on the Energy Performance of Buildings; Publications Office of the European Union: Brussels, Belgium, 2010.

22. Minister of Investment and Development of Republic of Poland. Announcement of the Minister of Investment and Development of April 8, 2019 on the Publication of the Uniform Text of the Ordinance of the Minister of Infrastructure on Technical Conditions to Be Met by Buildings and Their Location; The Prime Minister of Republic of Poland: Warsaw, Poland, 2019; Volume 2019. (In Polish)

23. The Polish Committee of Standardization. PN-EN ISO 6946:2017-10 Building Components and Building Elements-Thermal Resistance and Thermaltransmittance-Calculation Methods; The Polish Committee of Standardization: Warsaw, Poland, 2017.

24. The Polish Committee of Standardization. PN-EN 12831:2006. Heating Systems in Buildings—Method for Calculation of the Design Heat Load; The Polish Committee of Standardization: Warsaw, Poland, 2006. (In Polish)

25. Oleśkowicz-Popiel, C.; Wojtkowiak, J.; Prętka, I. Effect of surface cover on ground temperature season's fluctuations. Found. Civ. Environ. Eng. 2002, 1, 151-164.

26. Kowalski, J. Hydrogeology with Basic Geology, 3rd ed.; Wydawnictwo Uniwersytetu Przyrodniczego we Wrocławiu: Wrocław, Poland, 2007. (In Polish)

27. Majorowicz, J. Geothermal degree values in Poland within the 200-2500 m depth range. Kwart. Geol. 1971, 15, 891-900.

28. Nowicki, R.Z. Wody Podziemne Miast Wojewódzkich Polski; Państwowy Insytut Geologiczny: Warszawa, Poland, 2007.

29. Alpha Innotec. Manual Instruction LW 140(L)-LW 310(L); Alpha Innotec: Kasendorf, Germany, 2019. (In Polish)

30. The Polish Standardization Committee. Air Conditioners, Chillers for Liquid Cooling and Heat Pumps with Electrically Driven Compressors, for Heating and Cooling-Testing and Evaluation Under Non-Full Load Conditions and Calculation of Seasonal Capacity; The Polish Committee of Standardization: Warsaw, Poland, 2019. 
31. The Polish Committee of Standardization. Energy Performance of Buildings-Method of Calculation of the Design Heat Load_-Part 1: Space Heating Load, Module M3-3; The Polish Committee of Standardization: Warsaw, Poland, 2017.

32. Gajewski, A.; Siergiejuk, J.; Szulborski, K. Carbon dioxide emission while heating in selected European countries. Energy Build. 2013, 65, 197-204. [CrossRef]

33. PGE Obrót S.A. Struktura Paliw. 30 March 2020. Available online: https://pge-obrot.pl/pdf/933 (accessed on 19 August 2020).

34. Ciura, S. Opłaty dystrybucyjne związane z poborem mocy biernej przez odbiorców. Energ. Elektr. 2011, 2, 1-10.

35. European Union. 2013/114/EU. Official Journal of the European Union. 2013. Available online: https: //eur-lex.europa.eu/legal-content/RO/TXT/?uri=OJ:C:2013:114:FULL (accessed on 3 July 2020).

(C) 2020 by the authors. Licensee MDPI, Basel, Switzerland. This article is an open access article distributed under the terms and conditions of the Creative Commons Attribution (CC BY) license (http://creativecommons.org/licenses/by/4.0/). 